\title{
Attitudes of EFL Teachers Towards Intercultural Communicative Competence: a Turkish Foundation University Case
}

\author{
Metin ÇIRPAN ${ }^{1}$ \\ Osman SABUNCUOĞLU
}

\begin{abstract}
The purpose of this research study is to find out the extent of EFL teachers' awareness towards Intercultural Communicative Competence (ICC), draw attention to the importance of culture teaching and investigate opinions and beliefs of English Language Preparatory Program instructors working in a foundation university in İstanbul. Culture teaching has drawn considerable amount of attention over the past two decades since an important aspect of learning a foreign language is to learn its culture. In a world where non-native speakers vastly outnumber native speakers, gaining an intercultural perspective of the language is an indispensable part of language learning. However, there seems to be a lack of culture integration in EFL classrooms. Thus, this study aims to explore to what extent EFL teachers are culturally aware. The study was carried out with 40 EFL instructors working at an English Language preparatory program in a foundation university in İstanbul. The quantitative data were obtained through a questionnaire while the qualitative data were gathered through semi-structured interviews administered to 6 instructors. The findings of the study revealed that there is a discrepancy between instructors' perceptions and in class practices regarding ICC. Even though participants showed positive attitudes towards culture teaching, they were partly aware of ICC as a skill and seemed to fail in integrating ICC in their lessons. This research aimed to illustrates the relationship between culture and language through the researchers' perspectives, along with the benefits of culture teaching in EFL classrooms, offers critical insights into language
\end{abstract}

\footnotetext{
${ }^{1}$ Metin ÇIRPAN, MA student, Istanbul Aydin University, Institute of Social Sciences, English Language and Literature, metincirpan@live.com

${ }^{2}$ Assist. Prof. Dr. Osman SABUNCUOĞLU, Istanbul Aydin University, osmansabuncuoglu@aydin.edu.tr Doi num: 10.17932/IAU.EFD.2015.013/efd_v06i1006
} 
Attitudes of EFL Teachers Towards Intercultural Communicative Competence:

A Turkish Foundation University Case

instruction, investigating teacher views on culture teaching. Therefore, it makes a significant contribution to the current research on ICC. Based on the findings, recommendations to foster culture teaching through incorporating a cultural variety in EFL classrooms were provided.

Keywords: Culture, Communicative competence, Intercultural Communicative Competence, Integration of Intercultural Elements in Teaching English

\section{Dil Okutmanlarının Kültürlerarası İletişimsel Yeterliliğe Karşı Tutumları: Bir Vakıf Üniversitesi İncelemesi}

\section{$\ddot{\mathbf{O} z}$}

Buçalışmanınamacı, İstanbul' daeğitimveren birvakıfüniversitesinde görev yapmakta olan İngilizce hazırlık programı okutmanlarının kültürlerarası iletişimsel yeterliliğge karşı farkındalıklarını analiz etmek, kültüröğretiminin önemine dikkat çekmek ve kültür öğretimi ile alakalı okutmanların ders içi çalışmalarını araştırmaktır. Herhangi bir dili öğrenmenin önemli bir boyutunun o dilin kültürünü de öğrenmek olduğu gerçeği kültür öğretiminin son yıllarda dikkat çekmesine neden olmuştur. Ana dili İngilizce olmayan insanların, ana dili İngilizce olan nüfusa sayıca büyük üstünlük kurduğu günümüz dünyasında, kültürlerarası bir perspektife sahip olmak dil ediniminin vazgeçilmez bir unsuru haline gelmiştir. Ancak, İngiliz dili eğitimi sınıflarında kültürel bir entegrasyon eksikliği görülmektedir. Bu yüzden bu araştırma İngiliz dili eğitmenlerinin kültürel farkındalıklarını keşfetmeyi amaçlamaktadır. Araştırma, İstanbul'da eğitim veren bir vakıf üniversitesinin İngilizce hazırlık programında görev yapmakta olan 40 okutman ile gerçekleştirilmiştir. Veri toplama sürecinde veri üçlemesi yaklaşımı benimsenmiştir. Sayısal veriler iki farklı anket vasıtasıyla, niteliksel veri ise 6 okutman ile gerçekleştirilen yarı yapılandırılmış görüşmeler ile toplanılmıştır. Araştırmanın sonucunda okutmanların kültürlerarası iletişim algıları ile ders içi çalışmalarının farklılık gösterdiği görülmüştür. Katılımcıların kültür eğitimine yaklaşımları genellikle olumlu iken, bir beceri olarak kültürlerarası iletişimsel yeteneğin farkında olmadıkları ve derslerine entegre etmekte yetersiz kaldıkları sonucu ortaya çıkmıştır. Araştırma, dil ve kültür ilişkisini, kültür öğretiminin İngiliz dili eğitimi açısından faydaları ile birlikte, araştırmacıların bakış açılarıyla 
betimleyecek; eğitmenlerin kültür öğretimine yaklaşımlarını araştırarak dil eğitimine yönelik çözümsel öneriler sunacaktır. Bu sebeple, kültürlerarası iletişimsel yeterlilik araştırmalarına dikkate değer katkıda bulunacak; aynı zamanda eğitmenlerin kültürlerarası iletişimsel yeterlilik farkındalıklarını artıracaktır. İngiliz dili eğitimi sınıflarında kültürel çeşitliliğin artırılmasıyla kültür öğretimi teşvik edilmelidir.

Anahtar kelimeler: Kültür, İletişimsel yeterlilik, Kültürlerarası iletişimsel yeterlilik (ICC), Kültürlerarası iletişimsel yeterlilik entegrasyonu

\section{INTRODUCTION}

Culture has a huge impact on how people speak, and it affects the way people communicate with others dramatically. Possessing a sufficient amount of vocabulary and grammatical knowledge on a language does not mean speaking in that language fluently. "Words and rules only" do not define language any longer. Language now acts as a bridge to tie different cultures together. Hence, culture and language are intertwined; they cannot be separated. Even though one can learn to speak a language through explicit grammar and vocabulary instruction, they can only get to understand how language functions and what its rules are. Without having an awareness about its cultural aspect though, it is almost impossible to fully grasp a language. Byram (1997) supports this view and states, "Students cannot truly master the language until they have also mastered the cultural contexts in which the language occurs" (p. 28). In other words, culture is the ultimate tool through which people communicate with people from various cultural backgrounds effectively. Kramsch (1993) also believes "Culture and language have always been inseparable and closely bound together." (p.351). In isolation from each other, culture learning and language learning is impractical. Without having any cultural awareness, even a simple conversation might be disrupted or interrupted by "culture bumps." Archer (1991) describes a culture bump "as a phenomenon that occurs when an individual has expectations about another person's behaviour within a particular situation but encounters a different behaviour in that situation when interacting with an individual from a different culture" (p.335). These bumps may happen unexpectedly and last usually minutes, but they might have long lasting effects. Therefore, the detrimental effects 
Attitudes of EFL Teachers Towards Intercultural Communicative Competence:

A Turkish Foundation University Case

of these bumps should not be taken for granted as they break down the communicative act.

In a world where people are a click away from sharing and expressing opinions, ideas, knowledge, likes and dislikes through innumerable networks binding the globe at high-speed, the inevitable result is what we call "globalisation." Globalisation has an influence on politics, economics, culture and also language. In relation to language, it has brought about a new term called "intercultural competence" as opposed to "communicative competence." Hymes "(1967) defines the term communicative competence "as the knowledge of the grammar rules and language rules in a given context appropriately." in response to Noam Chomsky's linguistic competence (as cited in Byram, 1997, p.7). Communicative competence consists of four competencies: the linguistic (grammatical) competence, sociolinguistic competence, discourse competence and strategic competence. Celce-Murcia, Dörnyei and Thurrell (1995) have all made contributions to the term later. As for intercultural competence, a number of definitions have been put forward. Deardorff (2006) defines intercultural competence as "the skill to communicate effectively and accordingly in intercultural environment, based on certain attitudes, abilities, perceptions, and intercultural knowledge (p. 178-188). Deardoff (2006) also asserts "Cultural awareness, intercultural competence, cross-cultural competence and multi-cultural competence are the basic concepts which are to be handled in order to define the skill to develop an understanding of culture as an important corner stone of the communication" (p. 178-188). Within the light of all the explanations, it is natural to draw the conclusion that linguistic competence is to be nourished with cross-cultural knowledge for a sound communication to take place.

Language learning clearly necessitates cultural integration, a certain level of familiarity with the target culture. Sercu (2005) states that "Bringing a foreign language to the classroom means connecting learners to a world that is culturally different from their own”. (p. 1). In order to learn a language more comprehensively, learners should be exposed to cultural components as well. Once learners are knowledgeable of cultural diversity and are more aware of the skills that enable them to think critically and 
interpret the target culture without any prejudice, they will be able to get into more effective interactions and communicate easily. As a result, the part that culture plays in foreign language education is definitely indisputable.

\section{Statement of Purpose \& Problem}

The surge of interest in the necessity of culture teaching is nothing new; it has been a subject for much research all aiming to investigate the benefits and importance of integrating cultural aspects into language classrooms. Moreover, due to the effects of globalisation, a comparatively new notion, "Intercultural Communicative Competence" namely, has drawn a significant amount of attention recently, becoming a priority. According to Risager (1998), the concept of language learning that is "based on the concept of single culture associated with a specific people, a specific language, and normally with a specific territory" has evolved into the intercultural approach that rests on a concept of cultures as "structurally related to each other"(p.224). The literature published on ICC provides plentiful evidence that intercultural elements should be fully integrated into EFL classrooms. However, contrary to what current literature suggests, there is a tendency to ignore culture teaching in language classrooms and EFL instructors are inclined to pay little attention to intercultural aspects in their classes. Therefore, this research aims to explore and investigate the assumption that language instructors have pre-determined perceptions of ICC and they mainly incorporate what the course books have to offer. Arguing against this perception, Kramsch (1993) believes that culture should always be in the background starting from the first day of class, "ready to unsettle the good language learners when they expect it least, making evident the limitations of their hard-won communicative competence, challenging their ability to make sense of the world around them" (p.1). Overall, in the $21^{\text {st }}$ century globalizing world, culture and language are inseparable and ICC is a must-skill.

\section{Statement of Significance}

Culture learning is equally important as language learning and acquisition of a language is not complete without cultural knowledge and awareness towards specific intercultural elements as they are all intertwined. Hence, 
Attitudes of EFL Teachers Towards Intercultural Communicative Competence:

A Turkish Foundation University Case

this research makes a significant contribution to culture related areas in the field of ELT.

Firstly, this research investigates language instructors' understanding of intercultural communication and their attitudes towards ICC. It serves as an opportunity to improve the understanding, and thus the implementation of culture teaching in classrooms. Through illustration of various researchers' perspectives, it places particular emphasis on the inseparable relationship between language and culture.

Secondly, the research will contribute to the current literature of ICC by providing a deep and a clear understanding of the concept, pointing out to the significance of culture teaching in language classrooms.

Thirdly, EFL instructors' beliefs and opinions were gathered through an online questionnaire to reflect what culture and ICC mean for teachers themselves; and the semi-structured interviews were administered to reflect the current in-class practice of cross-cultural language teaching. This mixed-method approach yields better results in comparing theory (current literature) with practice. This comparison is genuinely required as culture - to this day - is not included in ELT programmes as a sub-skill. It is left underrated even though it is accepted that language learning cannot take place in isolation from culture. As a result, teachers are obviously not sure how to deal with the cultural elements they encounter in their classes unless they are explicitly provided by course books or course designers. In this regard, the results of this study provides insights on the role of teachers as facilitators of culture teaching.

It is assumed that the overall suggestions this research will provide after data analysis, will benefit EFL instructors, language institutions delivering lessons to international students or students from different ethnic minorities, EFL departments of schools from primary to tertiary level for further research and curriculum planners. 


\section{Research Questions}

The questions that would be addressed in this paper are as following:

I. How do EFL teachers define ICC?

II. What are EFL instructors' attitudes towards culture teaching?

III. How do EFL instructors integrate ICC into their teaching to foster intercultural awareness?

\section{METHOD}

\section{Setting and Participants}

Administering convenience sampling, the subjects that participated in this research are EFL instructors working at İstanbul Bilgi University English preparatory program. The study was carried out with 40 EFL instructors who teach different skills such as reading \& writing and main course component from entry level (A1) to exit level (B2) as described by the Common European Framework of Reference (CEFR) standards. The questionnaire was administered to 40 instructors. Among these, 6 instructors were selected for the semi-structured interviews to supplement the questionnaire. Information regarding gender, age and job experience variables was also gathered in the questionnaire, and these variables were not analysed statistically, and their significance was not observed. 27 of the respondents were female whereas 13 of the population were males. $37.5 \%$ of the instructors were between 20 and 30; 42.5\% were between 30 and $40 ; 20 \%$ were between 40 and 50 years of age. Teaching experience of the teachers was as follows: $1-4$ years $(25 \%), 5-9(27.5 \%), 10-14$ years $(27.5 \%)$, $15-19$ years $(12.5 \%)$, and more than 20 years $(7.5 \%)$.

\section{Data Collection Instruments}

This study adopts a mixed method research design to meet the aims of the research and administer a combination of quantitative and qualitative data collection tools. Quantitative data was collected in the form of a questionnaire and qualitative data was obtained in the form of semistructured interviews. Mixed method research design is embraced as this type of research design generates an overall level of trustworthiness for the research and it ensures a better triangulation of data gathered 
via quantitative and qualitative data collection tools. As Dörnyei (2007) observes, combining QUAN and QUAL methods offers the classic merit to increase the strengths and mitigate the weaknesses of the study. Holding similar views, Sandelowski (2003) claims that mixed method approach aims to achieve an elaborate and comprehensive understanding of a complex matter through triangulation, namely to validate one conclusion by presenting converging results obtained through different methods.

In order to reach a wider audience, a quantitative approach is embraced. The data collected was found to be useful in supplementing and extending the qualitative one. Moreover, carrying out a qualitative data collection in the form of interviews provided participants with the chance to make detailed explanations and thus provide an important contribution to the understanding of the subject matter in-depth.

To meet these mentioned research objectives, data collection was QUAN and QUAL respectively. The quantitative data was gathered through a questionnaire which was adopted from "the International Questionnaire" developed by Sercu et.al. (2005). During the semi-structured interviews, the participants will be asked three questions.

\section{Procedure}

As quantitative data preceded qualitative data in this research, the questionnaire was administered first. The questionnaire was prepared online and e-mailed to the 40 participants. The purpose of the study and necessary explanations were provided in the link and they were also provided in the introduction of the surveys as well. Online surveys are thought to be useful in two ways. First, they are not as time-consuming as the traditional way of printing out papers and distributing them to each participant. Second, the data collected is easily transferrable to data analysis tools. As Lefever \& Matthiasdottir (2007) state, pen-and-paper instrument is costly and bound to location and time whereas online questionnaires are more feasible in reaching a wider audience.

In the questionnaire, participants were asked to score a number of statements on a five-point scale, ranging from 'I strongly agree' to 'I strongly disagree'. The questionnaire consists of 15 statements concerning 
teacher attitudes towards culture teaching and their in-class practices related to ICC. Participants were asked to indicate what kind of culture teaching activities they practise during classroom teaching time. As for the interviews, a convenient time and place were chosen for those participants who seemed willing to participate. The interviews adopt a semi-structured design. The questions were designed in an attempt to get as many details from the interviewees as possible and thought thoroughly in that fashion. The participants were encouraged to elaborate on the subject matter as it is inherent in semi-structured interviews. As Griffee (2012) observes, "The interviewer is free to ask for clarification and even add follow-up questions" in this type of interviews (p. 160).

40 responses

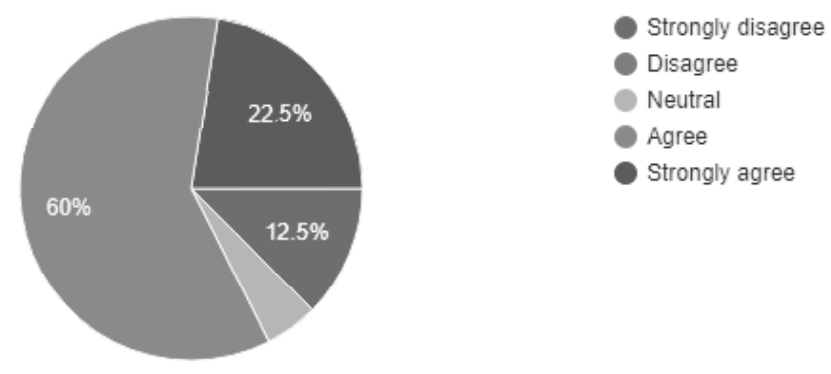

\section{Figure 1.}

$82.5 \%$ of the participants responded to this statement positively. $60 \%$ agreed and $22.5 \%$ strongly agreed. While only $5 \%$ was neutral, $12.5 \%$ thought otherwise and strongly disagreed. However, the majority concurred that teaching culture is as important as teaching the foreign language.

Statement 2: Before you can teach culture or do anything about the intercultural dimension of foreign language teaching, students have to possess a sufficiently high level of proficiency in the foreign language. 
40 responses

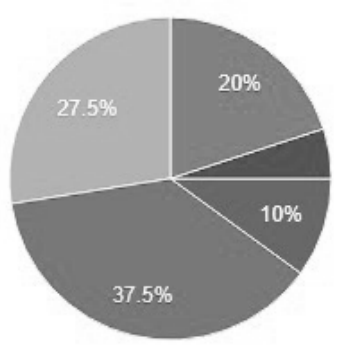

Strongly disagree

Disagree

Neutral

Agree

Strongly agree

\section{Figure 2.}

To this statement, $27.5 \%$ remained neutral, not stating an opinion. $47.5 \%$, almost half of the population disagreed with the statement that students have to possess a sufficiently high level of proficiency in the foreign language before you can teach culture. The remaining $25 \%$ believed students need a high level of proficiency to learn culture.

Statement 3: Intercultural skills cannot be acquired at school.

40 responses
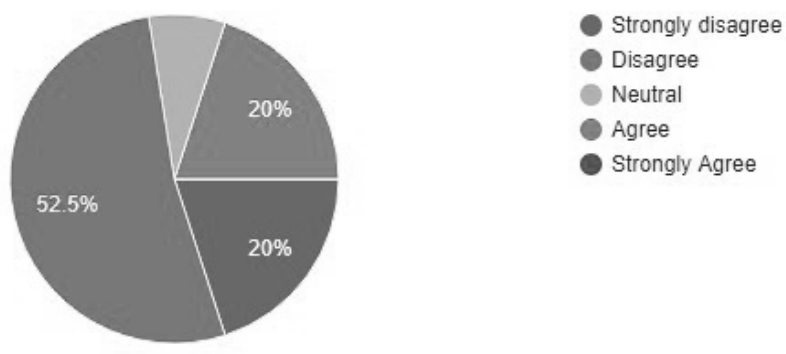

\section{Figure 3 .}

A whopping $72.5 \%$ of the respondents disagreed with the statement that intercultural skills cannot be acquired at school. Only $7.5 \%$ remained neutral. Interestingly, 20\% strongly agreed, believing school is not the place to gain intercultural skills. However, the overall consensus was that intercultural skills ought to be part of school curriculum. 
Statement 4: It is impossible to teach the foreign language and foreign culture in an integrated way.

40 responses

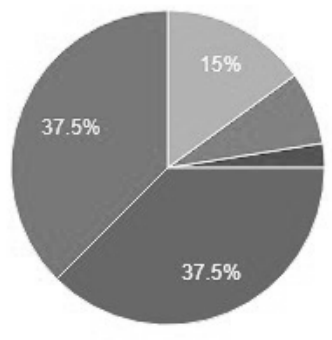

Strongly disagree

Disagree

Neutral

Agree

Strongly agree

\section{Figure 4 .}

A big majority of the participants (75\%) disagreed with this statement, claiming it is possible to teach culture and language in an integrated way. While $15 \%$ remained neutral, only $10 \%$ of the population claimed culture and language teaching should be separated.

Statement 5: The more students know about the foreign culture, the more tolerant they are.

40 responses

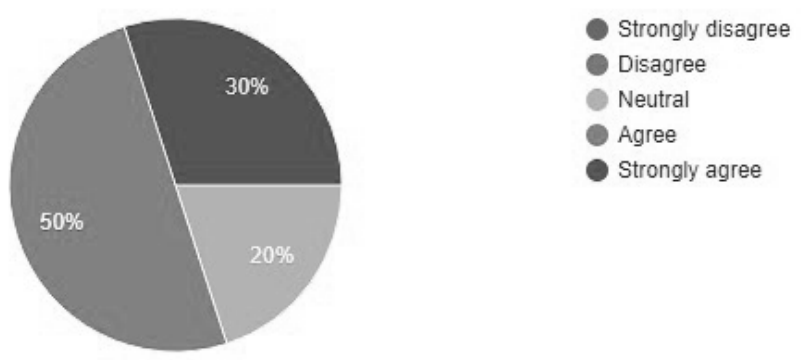

\section{Figure 5.}

The positive correlation between cultural awareness and tolerance is supported by the vast majority of the subjects, with $80 \%$ believing that students' tolerance towards other cultures increases as they are exposed to foreign cultures. $20 \%$ remained neutral while none of the subjects was opposed to this statement. 
Statement 6: Intercultural education reinforces students' already existing stereotypes of other people and cultures.

40 responses

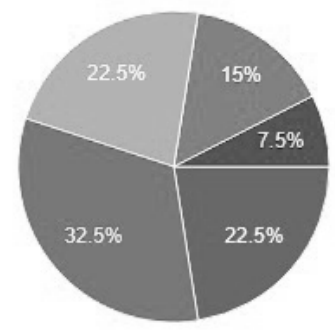

Strongly disagree

Disagree

Neutral

Agree

Strongly agree

\section{Figure 6.}

Similarly, more than half of the participants (55\%) claimed intercultural education does not reinforce students' already existing stereotypes of other people and cultures. $22.5 \%$ did not reveal positive or negative thoughts. It is interesting to note that $22.5 \%$ of the instructors believe intercultural education would make a negative impact on stereotypes.

Statement 7: Teaching culture motivates students to learn English.

40 responses

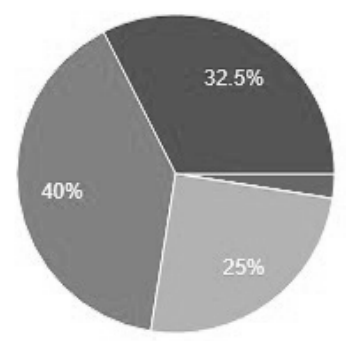

Strongly disagree

Disagree

Neutral

Agree

Strongly agree

\section{Figure 7.}

A big proportion of the participants $(72.5 \%)$ share the same opinion on the statement that learning more about culture motivates students to learn English. While only $2.5 \%$ of the population disagreed, $25 \%$ could not agree, not stating an opinion. 
Statement 8: Intercultural education has no effect what so ever on students'attitudes.

40 responses

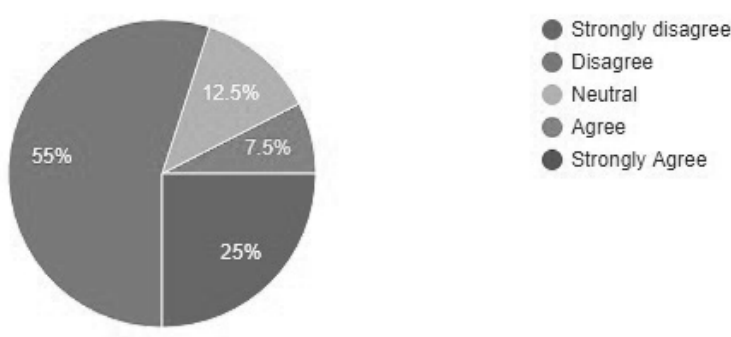

\section{Figure 8.}

32 out of 40 participants either disagreed or strongly disagreed with the $8^{\text {th }}$ statement, with a percentage of $80 \%$. A small number of participants (7.5\%) agreed that intercultural education does not have a positive effect on students' attitudes while the percentage of the subjects that could not make their mind on whether to agree or disagree was $12.5 \%$.

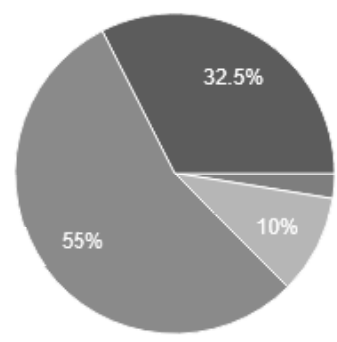

\section{Figure 9.}

Except for 5 of the whole subject group, 35 out of 40 instructors would like to promote the acquisition of intercultural skills through their teaching, with a whopping $87.5 \%$. The remaining $10 \%$ was undecided while only 1 instructor was not willing to promote the acquisition of intercultural skills in their classes. 
Statement 10: A foreign language teacher should present a realistic image of a foreign culture, so negative aspects of the cultures should also be presented.

40 responses

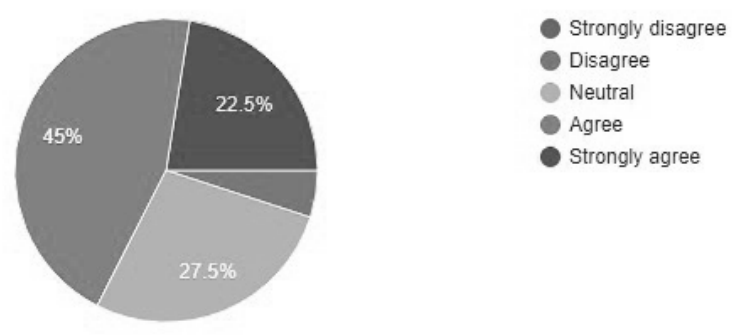

\section{Figure 10.}

With reference to this graph, it can be inferred that teachers should not be biased while presenting cultural aspects. $67.5 \%$ of instructors ( $45 \%$ agreed, $22.5 \%$ strongly agreed) responded positively to this statement. $27.5 \%$ was not sure about presenting a realist image of a foreign culture while only $5 \%$ disagreed.

Statement 11: I only teach the culture of English-speaking countries.

40 responses

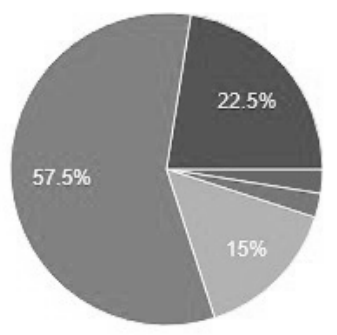

Figure 11. 
$40 \%$ disagreed and $12.5 \%$ strongly disagreed with the $11^{\text {th }}$ statement and asserted that they do not only focus on the culture of English-speaking countries. $30 \%$ of the participants responded positively. This means a significant number of teachers think students do not necessarily need to know about a variety of cultures. Therefore, they are only exposed to the cultures of English-speaking countries. $17.5 \%$ was indifferent to this statement.

Statement 12: Teaching cultural elements from all around the world is a waste of time.

40 responses
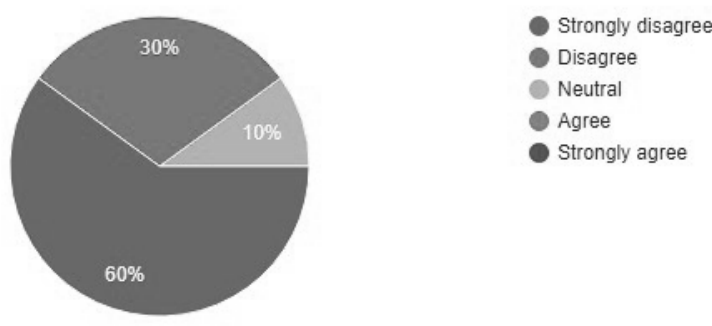

\section{Figure 12.}

Statement 12 is by far the most agreed upon item in the whole questionnaire, with $90 \%$ of the population revealing negative opinions $(30 \%$ disagreed and $60 \%$ strongly disagreed). This indicates that apart from the undecided 4 instructors, who make up $10 \%$ of the whole group, no one believes culture teaching is a waste of time. 
Statement 13: I include authentic materials to teach culture in my lessons.

40 responses

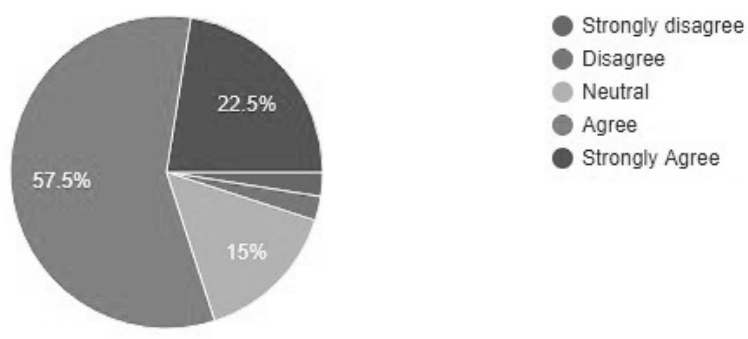

Figure 13.

A substantial number of participants agreed with the $13^{\text {th }}$ statement, with 32 instructors either agreeing or strongly agreeing. 57.5\% agreed and $22.5 \%$ strongly agreed, claiming they include authentic materials to teach culture in their lessons. Yet, $15 \%$ remain neutral and could not decide whether to include authentic materials or not. It is surprising to see that there are instructors who oppose the incorporation of authentic materials in language instruction, either disagreeing or disagreeing strongly, with $2.5 \%$ respectively.

Statement 14: I do not have time to incorporate cultural aspects in my lessons.

40 responses

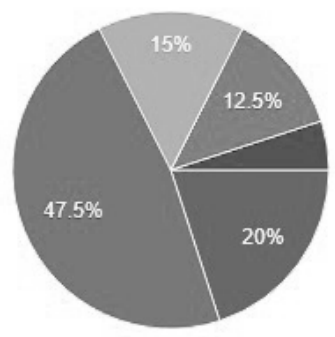

Strongly Agree

Figure 14. 
Statement 14 aims at finding about the time distributed over culture teaching. $67.5 \%$ of participants responded negatively $(47.5 \%$ disagreed, $20 \%$ strongly disagreed), claiming they have a sufficient amount of time to allocate for culture teaching. $12.5 \%$ agreed and another 5\% strongly agreed. This would mean that they are pressed for time due to the pacing of the course. The percentage of the participants who were not decided was $15 \%$, which indicates they are not sure whether they have time or not for inclusion of cultural aspects in their lessons.

Statement 15: Providing additional cultural information makes students more tolerant towards other cultures and people.

40 responses

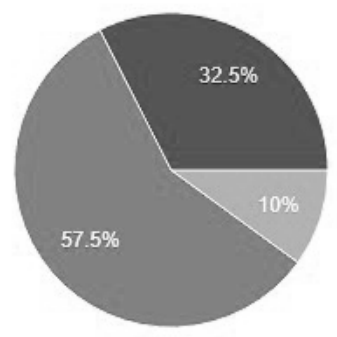

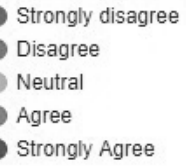

\section{Figure 15.}

None of the participants responded to this item negatively. While only $10 \%$ could not decide whether providing additional cultural information has a positive effect on tolerance towards other cultures and people, 36 out of 40 instructors, who make up $90 \%$ of the whole subject group, claimed that addition of culture into teaching increases students' tolerance towards other cultures and people.

\subsection{Results of the Interviews}

Question 1: What do you understand from the term "Intercultural Communicative Competence?"

The question aimed to find out about instructors' overall familiarity with the term itself. Even though none of the instructors could come up with a comprehensive definition, the overall impression is that they are mostly in 
line with the argument that cross-cultural competence nourishes linguistic competence. T1 thought that it means understanding the comprehension of the cultural elements (in both cultures) and their utilization while learning. T2 believes teaching a new language helps the learner to get to know the culture of that language and having knowledge about that culture leads to a more sound communication to take place and stated that culture and language are inevitably intertwined and most definitely affect one another. T3 said:

- Language barriers will sometimes be present, but beyond that it means to have cultural sensitivity and awareness while interacting with people who come from different countries. Navigating and appreciating cultural nuances play an important role in the development of relationships with people from around the world.

T4 held similar opinions and stated:

- It is a communication between a group of people of different cultures that can't be achieved without a level of self-awareness and ability to not listen to the other but also trying to understand and accept cultural diversity. it's also the ability to understand and interpret non-native language or behaviour or even gesture. Such a capacity requires integration in the foreign culture and acceptance of difference.

T5 believes that ICC refers to a range of cognitive, affective, and behavioural skills that leads to effective communication with people of other cultures. It involves an ability to understand and appreciate other people's behaviours and ways of thinking, willingness to accept and acknowledge the existence of opinions that one does not necessarily agree with, as well as a compromise between different cultural norms.

T6 emphasizes the importance of verbal expressions and gestures in having a decent understanding of other cultures. When learning a new language, the way people of that particular culture carry out meaning throughout expressions that go beyond simple words and sentences are stated to be of utmost importance. 
Question 2: What do you do in class to teach the cultural aspect of the language? Do you use additional teaching materials other than textbooks? If yes, what materials do you use and give reasons as to why you use them.

This question explores if there is gap between theory and practice. Moreover, it is aimed to find out what authentic materials - if any - instructors exploit in their teaching regarding culture. T1 clearly stated that he does not use any extra materials, but he tries to share anecdotes that he believes students might find interesting. T2 solely relies on what the textbooks have to offer with the assumption that textbooks provide teachers with quite a lot of materials to teach the cultural aspect of the language in terms of both verbal and non-verbal communication. She prefers to stick to those. As a native speaker of English, T3 takes any opportunity to share his stories about his time in Minnesota, the USA. He says:

- I believe all people have interesting stories or knowledge to share that give others authentic insight into their lives. I also try to share any interesting books, music, movies, or TV shows. Although our class schedule may be busy, I want to expose them to anything that might spark their interest in American culture.

T4 believes it is rudimentary to teach cultural aspects in a foreign language class and she uses different videos she has downloaded on the Internet that show differences between cultures. She also exposes students to authentic materials. By doing this, she means getting them exposed to the language native speakers use in their daily life using short videos for example. Moreover, she tries to compare students' own culture to the culture of language because they get excited to know what the differences are and what native speakers of the target language do in various situations.

T5 addressed a variety of cultural and linguistic aspects that he includes in his lessons and said:

- The materials I use include culture-based multimedia such as documentaries, music and images. This engages their visual senses, thereby keeping their interests alive. It also helps me communicate sociolinguistic, pragmatic competences - requests, advice, refusal, politeness, impoliteness, greetings, offers, etc.; non-verbal-greetings, 
Attitudes of EFL Teachers Towards Intercultural Communicative Competence:

A Turkish Foundation University Case

gestures, mimics, eye contact, etc; socio-cultural knowledge - traditions, food, housing, habits, etc. and help them develop intercultural awareness and tolerance.

T6 held similar views and pointed out to the importance of using videos that involve topics such as lifestyle, food, traditions and speeches of that culture. She added:

- Sometimes, I purposely present content that matches their culture so that students can learn both similarities and differences between their own culture and the target culture. I also use other materials and techniques like role play and drama where students adopt characters from that culture and live by it for a while, I find this a very effective way for students to have a full understanding of what they have been learning.

Overall, all the instructors share the same belief that bringing cultural topics into the class offers a variety of communicative opportunities for learners.

Question 3: How is your teaching time distributed over 'language teaching' and 'culture teaching'? Do you have the feeling that you would like to devote more time to 'culture teaching' during your foreign language teaching classes? If yes, what may be the reasons for that?

T1 did not elaborate on the question and said culture language learning cannot take place in isolation from cultural elements as this makes it harder for students to have a holistic understanding of what they get exposed to. T2 complains about time constraints, stating it takes a considerable amount of time to incorporate these kinds of teaching methods into the lessons and instructors do not always have sufficient time to do it. She added:

- I end up having to create a healthy balance between the most basic requirements of the course and the "ideal" way of teaching culture and language together in our programme. I would definitely like to have more time to devote to cultural teaching for I firmly believe it generates a more thorough and authentic understanding of the language for the learners. 
T3 shared similar opinions and said he spent more time with "language teaching" than he did with "culture teaching" in his class. He believes having a class period every week devoted to culture would be great, but the syllabus usually does not allow.

- I think they both play a crucial role in the development of my students, but the institution and the syllabus don't always take this into account. I try to pepper in as much "culture teaching" as I can, and I can say that my students appreciate it. They enjoy when I go off on a tangent during class and share a story or a song that I have fallen in love with. It would be great if we had a class period every week in which we could devote time to some unique, interesting aspects of different cultures.

T4 believes there is no clear cut between language and culture and added: - I teach a text about South African weddings through the foreign language English, so the medium is in itself target as well as tool. The objectives are thus twofold: teaching culture in South Africa where people speak the language in question English.

T5 does not believe that devoting time to culture teaching is an expedient. He continued:

- My approach is to infuse the British and American culture into every lesson and emphasize the cultural dynamics only when necessary. I also find myself explaining linguistic signs in light of cultural perspectives to both native and non-native speakers quite often, too.

On the other hand, he thinks culture and language are inseparable. Without clear distribution of time over the two, these cultural aspects need to be developed since the comparison between cultures is advisable to develop intercultural awareness and appreciation.

T6 similarly devotes more time for language teaching than culture teaching and says that she tries to include cultural topics as much as possible and the role of culture has been increasing gradually in her classes. 
Attitudes of EFL Teachers Towards Intercultural Communicative Competence:

A Turkish Foundation University Case

\section{DISCUSSION}

In an attempt to find out about the extent of EFL teachers' awareness of Intercultural Communicative Competence (ICC), three research questions were addressed in this study. The first research question of the study is: "How do EFL teachers define ICC?" Even though all the participants agree that culture teaching is an indispensable part of language learning, none of them seem to have heard about the term before. Thus, they tried to guess the meaning of the term and interpreted what it could mean. Mostly, they believed it is to communicate effectively with people from different cultures, also to understand them. They mostly had a general understanding of ICC, and stated it is should be a part of EFL classes apart from one participant who believes culture teaching is not their job.

The second question of the study is: "What are EFL instructors' attitudes towards culture teaching?" Majority of the participants had positive attitudes towards culture teaching. As can be seen in the questionnaire results, the majority of the teachers in the study believe that teaching culture is as important as teaching the foreign language in a foreign language classroom. They oppose the argument that students have to possess a sufficiently high level of proficiency in the foreign language before teaching them culture or do anything about the intercultural dimension of foreign language teaching. Also, half of the participants stated that intercultural skills can be acquired at school and three out of four respondents opposed the statement that it is impossible to teach the foreign language and foreign culture in an integrated way. Similarly, teachers hold the opinion that the more students know about the foreign culture, the more tolerant they become. In relation to the alleged effect of culture teaching on stereotypes, respondents feel that there is no apparent influence driven by intercultural education towards already existing stereotypes. Again, three out of four participants believe that culture teaching motivates learners to learn languages and almost all the participants would like to promote the acquisition of intercultural skills through their teaching. To reflect the target culture objectively, teachers stated that a foreign language teacher should present a realistic image of a foreign culture, so negative as well as positive aspects of the cultures should also be presented. The results of the last item in the questionnaire illustrate that the majority oppose the argument teaching cultural elements from all around the world is a waste of time. 
The overall impression was that language classes are the ideal settings to incorporate culture and teachers should be conscious of the fact that they ought to exploit cultural elements along with language.

The final question of the study is: "How do EFL instructors integrate ICC into their teaching to foster intercultural awareness?" In order to answer this question, both the items in the questionnaire and the questions in the interviews are used. Regarding the items in the questionnaire, $80 \%$ of the teachers stated that they include authentic materials to teach culture in their lessons. Almost $70 \%$ of them said they are able to find time to incorporate cultural aspects in their lessons. Interestingly, this shows a drastic contrast with the third interview question where some of the respondents complain about syllabus design or course pacing as an obstacle to culture teaching. Finally, teachers have contrasting opinions as to whose culture to teach. Almost half of them stated they only teach the culture of English-speaking countries whereas the other half disagreed.

The second question in the interview is aimed at exploring what teachers do in class to promote culture teaching and how they to it. The general tendency is towards using the textbooks as they provide a lot of materials to teach the cultural aspect of the language. Teachers sometimes share excerpts from interesting books, music, movies, or TV shows. They generally do not use any supplementary materials; share anecdotes that they believe students might find interesting. They believe giving students the opportunity to compare their own culture to the culture of the target language helps them to explore the differences and what native speakers of the target language do in various situations. Techniques like role playing and drama are found to be helpful in that they are effective ways to have a full understanding of what is being taught.

The overall impression is that teachers mostly rely on the textbook content and incorporate culture-based media to foster cultural awareness.

\section{CONCLUSION}

This study started with the intention of exploring teachers' cultural awareness and the extent to which they incorporate ICC into their teaching. It explored participants' thoughts and in-class practices regarding culture teaching. In the $21^{\text {st }}$ century world where globalisation connects cultures unprecedentedly, ICC as a skill should not be ignored or underestimated 
Attitudes of EFL Teachers Towards Intercultural Communicative Competence:

A Turkish Foundation University Case

by teachers. The findings of this study revealed that although majority of the teachers share positive attitudes towards culture teaching, there is a considerable amount of them that are still not aware of ICC in foreign language teaching. Another important fact that this study revealed is that teachers mostly ignore cultural aspects unless they appear on textbooks. They seem to give importance to cultural elements, however; these elements are not well integrated into lessons.

It is interesting to note that teachers stated conflicting opinions for some of the items in the questionnaire. The majority of the participants in the study believed ICC to be essential in language teaching and even asserted that teaching culture is as important as teaching the foreign language (as shown in figure 1 , with $82.5 \%$ having responded positively). However; the responses participants provided for statement 11 and statement 12 contradict with each other. $30 \%$ of the participants stated that they only teach the culture of English-speaking countries in statement 11. Even though more than half of the teachers responded negatively to this item, a significant number of teachers still hold the opinion that students do not necessarily need to know about a variety of cultures. These percentages pose a dilemma when the responses for statement 12 are also considered. $90 \%$ of the participants opposed the argument "Teaching cultural elements from all around the world is a waste of time." As a matter of fact, except for the undecided 4 instructors, who make up $10 \%$ of the whole group, no one believes teaching culture from around the world is a waste of time. Most teachers in this research consider culture as an indispensable aspect of language teaching, yet a high proportion of the same population only teach the culture of English-speaking countries in their classes. In this sense, the data shown in Figure 11 and Figure 12 clashes with the overall findings of the study. Even though teachers are conscious of the fact that they ought to exploit cultural elements along with language for the most part, there is no clearcut understanding as to what aspect or whose culture to exploit in classes. The questionnaire administered in this study was adopted from "Foreign Language Teachers and Intercultural Competence Questionnaire” developed by Sercu et.al. (2005), which is a comprehensive questionnaire consisting of 13 sections, collecting information on a vast array of topics ranging from culture teaching materials, cross-curricular activities, teachers' views on the aims of culture teaching and their intercultural effectiveness through administering a variety of scales. The research conducted by Sercu et.al. 
(2005) has been a guide for this investigation. Thus, the scope of this study does not allow for detailed disclosure or a resolution to mitigate this dilemma. However, with a larger sample size and a more detailed research design, future research could procure better results to address this contradiction.

The findings of this study have important pedagogical implications and suggest several actions to take. It is shown that most participants fail to incorporate culture unless they are addressed to in textbooks and this may be due to lack of training. Teacher training programmes should place more emphasis on the encouragement of promoting teachers towards culture teaching. Only in this way could teachers become more confident in preparing authentic materials that integrate ICC. Course designers should also be more aware of the matter and include ICC in the syllabus.

This study provides only a glimpse of a wide research area. It could be improved in different ways. First, it only includes 40 language instructors working at a single institution. More comprehensive results could have been achieved if a larger participant size had been included. Moreover, instructors who had been interviewed could have been observed to present the subject matter with detailed examples of teaching practices. As the relationship between teacher beliefs towards ICC and their inclass practices does not represent a straightforward connection, more understandable results could be attained through class observations.

\section{REFERENCES}

Archer, C. M., \& Nickson, S. C. (2012). The Role of Culture Bump in Developing Intercultural Communication Competency and Internationalizing Psychology Education. Psychology Learning \& Teaching, 11(3), 335-343.

Bandura, E., \& Sercu, L. (2005). Foreign language teachers and intercultural competence: an international investigation. Clevedon: Multilingual Matters.

Byram, M. (1997). Teaching and assessing intercultural communicative competence. Multilingual Matters.

Celce-Murcia, M., Dörnyei, Z., \& Thurrell, S. (1995). A pedagogical framework for communicative competence: A Pedagogically 
motivated model with content specifications. Issues in Applied Linguistics, 6(2), 5-35.

Deardorff, D. K. (2006). Identification and assessment of intercultural competence as a student outcome of internationalization. Journal of Studies in International Education, 10(3), 241-266.

Dörnyei, Z. (2007). Research methods in applied linguistics: Quantitative, qualitative, and mixed methodologies. Oxford: Oxford University Press.

Griffee, D. (2012). An Introduction to Second Language Research Methods. TESL-EJ Publications.

Hymes, D. (1967). Models of the interaction of language and social setting. Journal of Social Issues, 23(2), 8-38.

Hymes, D. (1972). On communicative competence. In J. Pride, \& J. Holmes (Eds.), Sociolinguistics: Selected Readings (pp. 269-293). Harmondsworth: Penguin.

Kramsch, C. (1993). Language study as boarder study: Experiencing difference. European Journal of Education, 28(3), 349-358.

Lefever, S., Dal, M., \& Matthiasdottir, A. (2007). Online data collection in academic research: advantages and limitations. British Journal of Educational Technology, 38(4), 574-582.

Meyer, M. (1991). Developing transcultural competence: case studies of advanced foreign language learners. In D. Buttjes \& M. Byram (Eds.), Mediating languages and cultures. Clevedon: Multilingual Matters.

Risager, K. (1998). Language teaching and the process of European integration. In M. Byram \& M. Fleming (eds.), Language Learning in Intercultural Perspective--Approaches Through Drama and Ethnography. Cambridge, Cambridge University Press, p.242-254.

Sandelowski, M. (2003). Tables or tableaux: The challenges of writing and reading mixed methods studies. In A. Tashakkori \& C. Teddlie (eds.), Handbook of mixed methods in social and behavioural research(pp. 321-350). Thousand Oaks, CA: Sage. 